\title{
KOMUNIKASI VERBAL PADA ANGGOTA KELUARGA YANG MEMILIKI ANAK INDIGO
}

\author{
VERBAL COMMUNICATION IN FAMILY MEMBERS WITH INDIGO CHILDREN
}

\section{Gregorius Fendi Arkandito, Eni Maryani, Deta Rahmawan, dan Teddy K. Wirakusumah}

\begin{abstract}
ABSTRAK
Gregorius Fendi Arkandito, 2016. "Komunikasi Pada Anggota Keluarga Yang Memiliki Anak Indigo". Dibantu oleh Achwan Noorlistyo Adi, S.I.Kom selaku rekan peneliti dan Duddy Zein, Drs., M.Si selaku dosen Program Studi Manajemen Komunikasi, Fakultas IImu Komunikasi, Universitas Padjadjaran.

Tujuan penelitian ini yaitu: 1) Untuk mengetahui komunikasi verbal pada keluarga dengan anak indigo. 2) Untuk mengetahui mengapa komunikasi verbal tersebut digunakan. 3) Untuk mengetahui proses penyampaian masalah anak indigo pada anggota keluarga lain. 4) Untuk mengetahui pengambilan keputusan pada keluarga tersebut.

Penelitian ini menggunakan metode kualitatif dan pendekatan studi kasus. Teknik utama dalam mengumpulkan data yaitu observasi, dan wawancara mendalam. Hasil penelitian yang diperoleh menunjukan bahwa komunikasi verbal yang digunakan anggota keluarga yang belum mempelajari indigo lebih dalam, lebih memilih komunikasi satu arah dan komunikasi verbal bersifat memerintah. Anggota keluarga lebih intens mendekati jika anak indigo mengalami atau melakukan hal negatif. Serta pembinaan yang digunakan adalah pembinaan pedagogi. Sedangkan anggota keluarga yang mempelajari indigo secara dalam, menggunakan komunikasi verbal yang lebih instruktif dan informatif. Tetap menjaga kadar emosi dari anak indigo tersebut agar tidak melewati batas wajar dan menggunakan pola pembinaan andragogi.
\end{abstract}

Kata Kunci : Komunikasi, Komunikasi Keluarga, Anak, Indigo 


\begin{abstract}
Gregorius Fendi Arkandito, 2016. "Verbal Communication in Family Members Who Have Indigo Children". Assisted by Achwan Noorlistyo Adi, S.I.Kom as a research fellow and Duddy Zein, Drs., M.Si as lecturer of Communication Management Studies Program, Faculty of Communication, University of Padjadjaran.

The purpose of this study are: 1) To determine the verbal communication in families with indigo children. 2) To find out why the use of verbal communication. 3) To know the process of addressing issues of indigo children in other family members. 4) To know the decision to the family.

This study used qualitative methods and case study approach. The main technique in collecting data, observation, and interview. The results obtained showed that verbal communication is used family members who have not learned the deeper indigo, preferring one-way communication and verbal communication are ruled. More intense closer to family members if the indigo children experiencing or doing negative things. As well as coaching is coaching pedagogy used. Meanwhile, family members learn indigo deeply, using verbal communication is more instructive and informative. While maintaining the emotional content of the indigo children that do not cross reasonable limits and to use development patterns Andragogy.
\end{abstract}

Keywords: Communication, Family, Children, Indigo

\title{
LATAR BELAKANG
}

Indigo, mungkin jika mendengar kata tersebut kita akan langsung tertuju kepada seseorang yang bisa melihat makhluk-mahkluk yang tidak bisa dilihat oleh manusia biasa seperti hantu atau roh halus. Sebenarnya, konsep anak indigo pertama kali dikemukakan oleh Nancy Ann Tappe pada tahun 1970-an. Pada tahun 1982, Tappe menerbitkan sebuah buku yang berjudul Understanding Your Life Through Color yang menjelaskan bahwa, ia menyadari pada tahun 1960-an ada banyak anak yang lahir dengan aura "indigo". Tappe juga menjelaskan pada publikasi lainnya bahwa warna indigo atau nila berasal dari "warna kehidupan" anak yang dia dapatkan dari sinestesia. Jadi seorang anak disebut indigo dikarenakan oleh aura yang dimiliki oleh anak tersebut memiliki warna nila atau indigo. 
Dengan kata lain, Tappe membagi-bagi zaman di dunia ini melalui warna. Unsur mistik dan anak indigo nampaknya dua hal yang sulit dipisahkan, sebab anak indigo juga dianggap memiliki kemampuan-kemampuan khusus supranatural seperti telepati, kemampuan melihat keadaan yang terjadi di tempat lain, kemampuan memprediksi dan membuat prediksi itu terjadi, kemampuan flashback, menggali informasi dan berkomunikasi dengan objek apa saja, hipnotis, telekinesis sehingga anak indigo punya kemampuan menggerakkan benda dari jarak jauh, dan terakhir anak indigo dipercaya bisa berkomunikasi langsung dengan Tuhan. ${ }^{1}$

Jan Yordy seorang terapis yang menulis mengenai anak indigo mencoba mengkategorikan karakteristik anak indigo yang sering ditemui, yaitu:

Memiliki keinginan yang kuat, mandiri dengan melakukan apa yang ada di pikirannya daripada mematuhi kehendak orangtua, bijaksana dan memiliki tingkat kesadaran dan kebersamaan yang melebihi pengalamannya;

Secara emosi, mereka dapat dengan mudahnya bereaksi sehingga tidak jarang mereka memiliki permasalahan dengan kecemasan, depresi atau stress;

Kreatif dalam berpikir dengan menggunakan otak kanan namun tetap harus berusaha belajar dengan menggunakan otak kiri terutama pada sistem di sekolah; anak indigo sering didiagnosis mengalami ADD (attention deficit disorder) atau ADHD (attentiondeficit hyperactivity disorder) saat mereka menunjukkan perilaku impulsive (otak mereka memproses informasi lebih cepat) dan mereka harus tetap bergerak agar selalu fokus;

Anak ini sangatlah peka dan dapat melihat, mendengar atau mengetahui sesuatu hal yang tidak dimiliki orang kebanyakan;

Anak-anak ini belajar secara visual dan kinestetik, mereka dapat mengingat apa yang terekam dalam otak dan menciptakan melalui tangan;

Apabila keinginan anak tidak terpenuhi, maka anak merasa kesulitan dan menjadi self centered. Meskipun hal ini bukanlah sifat sebenarnya; anak memiliki potensi dan bakat yang luar biasa, namun dapat hilang begitu saja jika tidak sesuai dengan bentuk pengasuhan. $^{2}$

\footnotetext{
${ }^{1}$ http://www.mediametafisika.com/2013/06/hal-yang-menarik-dari-anak-indigo.html diakses pada 18 Juni 2015

${ }^{2}$ http://www.indospiritual.com/artikel_mengenal-karakteristik-anak-indigo.html\#.VP3MffmsWYA
} 
Jika dilihat dari beberapa penjelasan dan contoh kasus di atas, seorang anak indigo sebenarnya memiliki banyak kemampuan yang tidak dimiliki anak-anak pada umumnya. Namun, dikarenakan pemikiran orang-orang yang selalu menyangkut pautkan indigo dengan hal-hal mistis banyak anak indigo yang hanya ditanyai oleh teman-temannya atau bahkan anggota keluarga mengenai hal-hal yang berbau mistis. Contohnya: "di sekolah kita katanya ada kuntilanak, kamu bisa lihat tidak lokasinya ada di sebelah mana?" Berdasarkan hasil wawancara pra riset saya kepada informan yang tidak ingin disebutkan namanya, ia sering ditanyakan mengenai hal-hal mistis oleh teman-teman dan adiknya sendiri. ${ }^{3}$

Jika dilihat dari jumlah anak indigo di indonesia, menurut dr. Erwin, pendiri Yayasan Peduli Pendidikan Anak Indigo di Indonesia, jumlahnya belum mencapai ratusan. Tapi dari jumlah yang sangat sedikit itu, beliau mengharapkan bahwa jika mendapatkan pendidikan dan pembinaan yang tepat maka mereka akan menjadi pemimpin yang bijaksana, humoris dan cinta damai. ${ }^{4}$

Konsep keluarga sangat tergantung dari konteks masyarakat di mana teori atau konsep tentang keluarga dilahirkan. Di masyarakat dengan budaya Barat, keluarga bisa terbentuk baik dengan atau tanpa ikatan perkawinan yang sah. Di budaya Timur, yang disebut keluarga adalah mereka yang terikat dalam ikatan perkawinan yang sah (Sumarwan, 2004:229). Komunikasi verbal keluarga sangat mempengaruhi kepuasan para anggota keluarga yang terdapat di dalamnya. Komunikasi verbal tercermin dari cara orang tua membangun komunikasi dengan anak. Selain itu keluarga merupakan kelompok primer yang merupakan kelompok di mana komunikasi yang terdapat pada kelompok ini bersifat mendalam. Pada kelompok primer biasanya hal-hal yang bersifat pribadi diungkapkan, namun dalam kasus ini sedikit berbeda. Seorang anak indigo agak malu atau enggan untuk mengungkapkan kepada anggota keluarga mereka yang lainnya jika diri mereka adalah seorang indigo. Padahal keluarga adalah lingkungan pertama yang dikenal oleh seorang anak dan keluarga pula lah yang sangat berperan bagi perkembangan anak. Seorang anak indigo biasanya hanya diam dan tidak bisa mengungkapkan dengan bebas apa yang terjadi dengan dirinya tersebut. Banyak orang tua yang masih acuh terhadap anak mereka yang merupakan

\footnotetext{
${ }^{3}$ Hasil pra riset dengan informan yang tidak ingin disebutkan namanya

${ }^{4} \mathrm{http}$ ://mediaonlinenews.com/lain-lain/fenomena-anak-indigo
} 
anak indigo dan tidak sedikit pula orang tua yang menganggap keadaan anak mereka yang seperti itu adalah sebuah penyakit kejiwaan.

Seorang anak indigo pasti ingin menjelaskan mengenai keadaan dirinya dan apa saja yang dia lihat kepada keluarganya. Berdasarkan paparan di atas, peneliti tertarik untuk meneliti mengenai, "Komunikasi Verbal Pada Anggota Keluarga yang Memiliki Anak Indigo".

\section{METODE}

Untuk melakukan penelitian mengenai komunikasi verbal pada keluarga yang memiliki anak indigo ini, peneliti memutuskan untuk menggunakan metode penelitian kualitatif. Peneliti menggunakan metode penelitian kualitatif dikarenakan pendapat tiap-tiap anggota keluarga pasti berbeda-beda. Dan juga karena sifat dari pendekatan kualitatif yang mengatakan bahwa realitas bersifat ganda, rumit, dinamis, dan kebenaran realitas bersifat dinamis. (Mulyana, 2013:147).

Selain itu, penelitian kualitatif adalah proses penelitian dan pemahaman yang didasarkan pada metodologi yang menyelidiki suatu fenomena sosial dan masalah manusia. Pada pendekatan ini, peneliti membuat suatu gambaran kompleks, meneliti kata-kata, laporan terinci dari pandangan responden, dan melakukan studi pada situasi yang alami (Creswell, 1998:15).

Menurut Jane Richie (dalam Moleong, 2012) penelitian kualitatif adalah upaya untuk menyajikan dunia sosial, dan perspektifnya di dalam dunia, dari segi konsep, perilaku, persepsi, dan persoalan tentang manusia yang diteliti.

Dalam perkembangannya, penelitian kualitatif juga mendapat keraguan dari para peneliti positivis. Menurut mereka penelitian kualitatif tidak bisa dikategorikan penelitian ilmiah, karena tidak memiliki data yang akurat. Namun para peneliti postpositivis yang meluruskan pandangan tersebut. Penelitian kualitatif dengan paradigma post positivis melihat sebuah realitas dengan lebih dalam, tidak hanya dipermukaan sebuah realitas tersebut melainkan hingga pemaknaan dan motif realitas itu. Selain itu, meneliti fenomena tersebut tidak bisa perbagian, karena realitas sifatnya adalah suatu bagian yang utuh (holistik). ${ }^{5}$

\footnotetext{
${ }^{5}$ Lexy. J Moleong, 2012. Metodologi Penelitian Kualitatif edisi revisi 2012. Bandung: Remaja Rosdakarya, hlmn: 5
} 
Untuk menjawab keraguan tersebut, maka penelitian kualitatif menggunakan dasar pendekatan alamiah pada setiap pengumpulan data dan pengolahan data yang didapat dari sumber informasi. David Williams (1995) menulis bahwa penelitian kualitatif adalah pengumpulan data pada suatu latar alamiah, dengan menggunakan metode alamiah, dan dilakukan oleh orang atau peneliti yang tertarik secara ilmiah.

Penelitian kualitatif dari sisi definisi lainnya dikemukakan bahwa hal itu merupakan penelitian yang memanfaatkan wawancara terbuka untuk menelaah dan memahami sikap, pandangan, perasaan, dan perilaku baik individu maupun sekelompok orang. Dari definisi ini, peneliti menyimpulkan bahwa hanya mempersoalkan satu metode untuk mendapatkan hasil yaitu dengan cara wawancara terbuka.

Untuk melaksanakan penelitian ini, peneliti menggunakan pendekatan studi kasus eksplanatoris. Definisi studi kasus sebagai suatu strategi penelitian adalah studi kasus adalah inkuiri empiris yang: (Yin, 2002)

a. Menyelidiki fenomena dalam konteks kehidupan nyata, bilamana:

b. Batas-batas antara fenomena dan konteks tak tampak dengan tegas; dan di mana:

c. Multisumber buku dimanfaatkan.

Selain itu, penelitian studi kasus juga memiliki tempat tersendiri dalam penelitian evaluasi. Dalam hal ini, ada empat aplikasi yang berbeda, yaitu: (Yin, 2002):

1. Menjelaskan keterkaitan kausal dalam intervensi kehidupan nyata yang terlalu kompleks bagi strategi survei ataupun eksperimen.

2. Mendeskripsikan konteks kehidupan nyata di mana intervensi telah terjadi.

3. Evaluasi bisa memberi keuntungan, sekali lagi dalam bentuk deskriptif, dari studi kasus ilustratif - bahkan pemikiran jurnalistik - tentang intervensi itu sendiri.

4. Strategi studi kasus bisa digunakan untuk mengeksplorasi situasi-situasi di mana intervensi yang akan dievaluasi tidak memiliki struktur hasil yang tunggal dan jelas.

Studi kasus eksplanatoris adalah studi kasus yang mengarah kepada penggunaan pertanyaan-pertanyaan "bagaimana" dan "mengapa". Itu dikarenakan pertanyaan-pertanyaan seperti itu berkenaan dengan kaitan-kaitan operasional ynag menuntut pelacakan waktu tersendiri, dan bukan sekedar frekuensi waktu kemunculan (Yin, 2002). 
Berdasarkan dari kasus yang di teliti, peneliti menggunakan studi kasus tunggal. Dalam suatu penelitian dikatakan cocok menggunakan studi kasus tunggal jika: (Yin, 2002):

a. Kasus tersebut dikatakan penting dalam dalam menguji suatu teori yang telah disusun dengan baik.

b. Kasus tersebut menyajikan suatu kasus yang ekstrem atau unik.

c. Kasus tersebut merupakan kasus penyingkapan.

Dan juga studi kasus yang digunakan oleh peneliti adalah studi kasus dengan desain terjalin. Peneliti menggunakan studi kasus dengan desain terjalin karena dengan desain tersebut peneliti bisa mengatasi perubahan-perubahan arah orientasi yang bisa terjadi kapan saja pada saat penelitian sedang berlangsung.

\section{HASIL PENELITIAN DAN PEMBAHASAN}

Anak indigo sering menyampaikan masalah yang menyangkut tentang keindigoannya kepada mamanya. Karena memiliki perbedaan dengan anak lainnya, di sekolah, anak indigo pernah diolok oleh gurunya atau temannya dengan sebutan dukun. Anaknya juga menyampaikan bahwa pernah mengalami konflik dengan guru yang tidak percaya dengan ucapannya, padahal dia sudah mengatakan hal yang sebenarnya.

Dan menurut Ayah anak indigo, dalam menyampaikan masalah, anaknya tidak perlu dipancing. Anaknya akan langsung cerita ke mamanya tanpa harus dipancing terlebih dahulu.

Menurut Ibu anak indigo, anaknya juga akan bercerita langsung kepada dirinya jika sedang mempunyai atau menghadapi suatu masalah tanpa harus dipancing terlebih dahulu. Dan Ibu anak indigo juga mengatakan bahwa selain dari anaknya sendiri, dia bisa mengetahui bahwa anaknya memiliki atau sedang menghadapi suatu masalah dari temannya. Salah satu contoh lbu anak indigo mengetahui anaknya sedang menghadapi sebuah masalah adalah ketika anaknya sedang dikerjai oleh gurunya. Sedangkan jika masalah itu ternyata adalah masalah anak itu sendiri, biasanya anak itu akan bercerita langsung. Jadi lbu anak indigo mengetahuinya dari anaknya sendiri.

Anak indigo mengatakan bahwa dia terbuka kepada keluarga secara tidak sengaja. Dia mengatakan bahwa kejadian itu terjadi saat dari berusia 4,5 tahun. Saat 
itu dia mengatakan bahwa ada seorang temannya datang ke rumah untuk bermain, tetapi anggota keluarga yang lain tidak melihat teman anak indigo pada waktu itu. Dan sejak saat itu jika dia memiliki pengalaman seperti itu, dia selalu bercerita ke mamanya.

Dan anak indigo mengatakan saat dia sudah bisa terbuka kepada keluarganya mengenai dirinya yang seorang indigo, dia merasa senang dan merasa lebih lepas. Menurut dia jika tidak bisa terbuka kepada keluarga, dirinya juga tidak merasa nyaman. Anak indigo menyampaikan mengenai pengalaman-pengalaman yang dia alami itu secara langsung. Setelah dia menceritakan itu, mamanya akan menyuruh dia untuk menyatat itu semua, sehingga dia tidak lupa. Pun alasan dia kenapa dia bisa langsung cerita seperti itu adalah dia akan cerita jika mamanya percaya. Menurut dia kepercayaan orang lain terhadap cerita dia mengenai pengalaman dan apa saja yang dia saksikan adalah hal terpenting, dan kepercayaan dari orang lain itulah yang bisa membuat dia terbuka kepada orang lain terutama keluarganya. Dan orang pertama yang diceritakan oleh anak indigo mengenai pengalaman-pengalaman dia adalah mamanya.

Dia juga bercerita mengenai perasaan dia jika sedang merasakan emosi sedih. Tetapi, dia tidak mengungkapkan semuanya. Dia hanya bercerita pengalaman yang membuat dia sedih itu sebagian saja. Dia hanya menceritakan bagian yang menurut dia patut untuk diceritakan ke orang lain. anak indigo bisa membagi hal-hal apa saja yang boleh dibagikan ke orang lain dan hal-hal apa saja yang tidak boleh dibagi atau diceritakan ke orang lain. Dan dalam hal pengalaman yang membuat sedih ini orang pertama yang menjadi tempat anak indigo berbagi cerita adalah mamanya. Dia juga pernah bercerita mengenai pengalaman yang menyedihkan ini kepada temannya, tetapi dia lebih sering bercerita ke keluarga terutama mamanya.

Anak indigo juga mengatakan bahwa dia juga pernah mengalami sebuah pengalaman yang membuat dirinya senang dan gembira. Dia mengatakan bahwa untuk hal itu dia berbagi cerita melihat di mana dia mendapatkan pengalaman yang menyenangkan tersebut. Jika dia mendapatkan pengalaman yang menyenangkan itu di sekolah, maka dia akan bercerita kepada temannya terlebih dahulu. Tetapi, anggota keluarga yang akan dia ceritakan pertama kali mengenai pengalaman yang menyenangkan itu adalah mamanya. 
Anak indigo juga pernah mengalami saat dia merasa takut akan suatu hal. Dia mengatakan jika dia takut, dia lebih memilih untuk diam terlebih dahulu. Setelah dia diam maka dia akan perlahan-lahan akan menjadi berani dan tidak merasa takut lagi. Tetapi, lain ceritanya jika dia sudah mengalami ketakutan yang sangat besar. Jika dia sudah mengalami ketakutan yang besar, dia akan lebih memilih untuk bercerita ke mamanya.

Jika anak indigo sedang menghadapi masalah seperti itu, dia jarang menceritakan atau berbagi cerita mengenai masalahnya tersebut kepada temantemannya. Dia lebih memilih untuk bercerita kepada keluarganya. Dan dari anggota keluarganya tersebut, orang yang dia pilih untuk menjadi tempat berbagi cerita mengenai masalahnya tersebut adalah mamanya.

Dari beberapa pertanyaan yang disampaikan peneliti kepada anak indigo, anak indigo menjawab bahwa mamanya adalah orang pertama yang dia ceritakan mengenai pengalaman-pengalaman yang dia dapat. Baik itu pengalaman yang menyedihkan, menyenangkan, menakutkan, ataupun pengalaman di mana dia sedang menghadapi suatu masalah. anak indigo memiliki alasan mengapa dia lebih memilih mamanya sebagai orang yang pertama kali dia bagikan pengalaman-pengalaman yang dia alami tersebut.

Anak indigo mengatakan bahwa dia lebih memilih bercerita ke mamaya mengenai pengalaman-pengalaman yang dia alami karena diantara semua anggota keluarganya, dia paling dekat dengan mamanya. Dan juga sejak kecil mamanya-lah yang mendampingi anak indigo dalam hal indigo maupun tidak indigo. Dan dari jawaban sebelumnya, anak indigo lebih memilih mamanya sebagai orang yang pertama kali dia bagikan pengalaman dia adalah karena mamanya percaya dengan ucapan anak indigo.

Pada saat anaknya mempunyai masalah dengan gurunya di sekolah, seperti yang sudah peneliti sampaikan tadi, Ayah anak indigo membantu anaknya dengan memberikan masukan agar anaknya menghadapi masalah itu dengan menghadap langsung ke guru yang mempunyai masalah dengannya. Tapi dibalik itu ayah anak indigo secara diam-diam bertemu dengan guru tersebut dan berbicara bahwa anaknya tidak suka dipanggil dukun. Tetapi, ayah anak indigo tidak mengatakan hal itu kepada anaknya sehingga anaknya berani untuk maju dan berusaha menyelesaikan permasalahan itu dengan bertemu dengan gurunya langsung. 
Dan dalam mengambil keputusan untuk penyelesaian masalah itu biasa diambil oleh mamanya. Namun, tidak jarang juga anak indigo yang mengambil keputusan untuk menyelesaikan masalah tersebut. Papa anak indigo mengatakan, bahwa anaknya memiliki pemikiran seperti orang dewasa. Jadi anaknya bisa mengambil keputusan sendiri dalam menyelesaikan masalahnya.

Jika bersamaan ayah dan ibu anak indigo maka dilihat dahulu permasalahannya lebih condong ke siapa, jika lebih condong ke ibunya maka ibunya yang menyampaikan dan Papa anak indigo melengkapi. Jika lebih condong ke Papa anak indigo, maka Papa anak indigo yang menyampaikan dan istrinya melengkapi.

Mama anak indigo memberikan jawaban yang agak berbeda dalam hal ini. Mama anak indigo mengatakan bahwa dalam membantu memecahkan masalah yang dihadapi anaknya, dia akan menganalisis masalah itu bersama-sama dahulu, kemudian mencari solusinya bersama. Dan Mama anak indigo selalu memberikan sisi positif dan sisi negatif dari tiap-tiap pemecahan masalah yang didapatkan.

Dan dalam mengambil keputusan dalam memberitahukan segala konsekuensi dari penyelesaian masalah yang di dapat, Mama anak indigo melihat situasi terlebih dahulu mengenai siapa yang mengambil keputusan tersebut. Jika masalah yang dihadapi oleh anaknya tidak terlalu besar, maka bisa dia sendiri yang memberikan itu. Jika masalahnya itu cakupannya luas, maka Mama anak indigo akan merundingkan hal tersebut dengan anaknya dan suaminya terlebih dahulu.

Dan mengenai orang yang menyampaikan penyelesaian masalah serta konsekuensi yang didapat dari setiap penyelesaian masalah tersebut lebih sering disampaikan oleh Mama anak indigo. Alasannya adalah karena memang anaknya lebih dekat dengannya dan dulu saat anaknya bercerita ke papanya, papanya tidak percaya kepada omongan anaknya dan anaknya dianggap berbohong.

Dalam menyelesaikan masalah yang dialami oleh anak indigo, anggota keluarga harus menerangkan dengan bijaksana dan tidak bohong. Penjelasan yang disampaikan dengan jelas tersebut bertujuan agar anak indigo mengerti dan tidak bertanya-tanya lagi.

Dan mengenai siapa yang lebih tepat untuk menyampaikan penyelesaian masalah tersebut, siapapun bisa melakukannya, yang penting orang tersebut menyampaikan penyelesaian masalah secara bijaksana dan tidak bohong. 
Dalam memberi penyelesaian masalah Papa anak indigo memberikan masukan walaupun dia diam-diam bertemu dengan orang yang memiliki masalah dengan anak indigo. Dan Papa anak indigo menyuruh anak indigo untuk menyelesaikan masalahnya jika sudah mendapatkan masukan dari Papanya. Itu bertujuan untuk membuat anak indigo menjadi lebih mandiri.

Mama anak indigo akan menganalisis bersama-sama masalah yang dialami oleh anak indigo. Lalu dia akan memberikan sisi negatif dan positif dari penyelesaian masalah tersebut. Dan lebih menyerahkan kepada anak indigo untuk menyelesaiakan dan mengambil keputusan untuk permasalahan yang sedang dialami oleh anak indigo. Mama anak indigo juga menggunakan komunikasi dua arah dalam menyampaikan penyelesaian masalahnya tersebut. Dan penyelesaian masalah tersebut lebih sering disampaikan oleh Mama anak indigo karena ia lebih dekat dengan anak indigo.

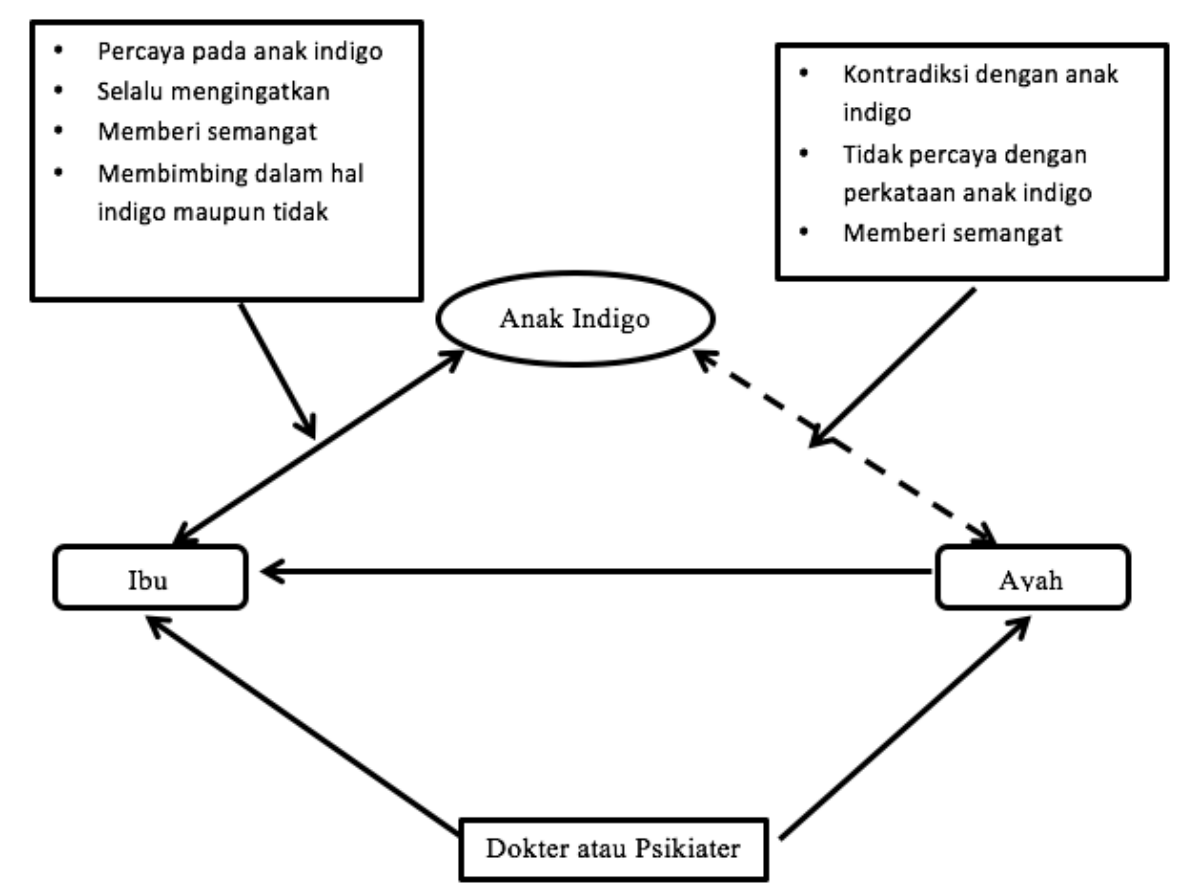

1. Model Komunikasi Verbal Pada Anggota Keluarga yang Memiliki Anak Indigo 


\section{SIMPULAN DAN SARAN}

Setelah melakukan penelitian dan menganalisis mengenai pola komunikasi keluarga yang memiliki anak indigo, peneliti dapat mengambil beberapa simpulan, yaitu:

1. Komunikasi verbal dan nonverbal yang digunakan pada anggota keluarga yang belum mempelajari indigo lebih dalam, lebih melihat pada apa yang terjadi kepada anak indigo tersebut. Lalu anggota keluarga lebih memilih komunikasi satu arah dan komunikasi verbal dan nonverbal yang bersifat memerintah atau mengancam. Anggota keluarga lebih intens mendekati jika anak indigo mengalami atau melakukan hal negatif, jika hal positif dilakukan atau dialami oleh anak indigo tersebut, maka anggota keluarga lebih memilih diam karena tidak ada yang perlu dikhawatirkan. Serta pembinaan yang digunakan adalah pembinaan pedagogi. Dan pola komunikasi yang digunakan adalah the unbalance split pattern, di mana hanya ada seorang pasangan atau anggota keluarga yang tampak lebih dominan dan menguasai lebih dari separuh keputusan dalam keluarga. Sedangkan bagi keluarga yang sudah mempelajari indigo secara dalam, anggota keluarga menggunakan komunikasi verbal dan non verbal yang lebih instruktif dan informatif, contohnya dengan menggunakan komunikasi dua arah, menanyakan anak indigo dengan lebih intens dalam berbagai kondisi, mau menghampiri anak indigo terlebih dahulu, memberikan argumen serta mau mendengar argumen dari anak indigo tersebut, tetap menjaga kadar emosi dari anak indigo tersebut agar tidak melewati batas wajar, dan menggunakan pola pembinaan andragogi. Dan mereka menggunakan pola komunikasi the balance split pattern, dimana setiap individu dalam keluarga tersebut memiliki peran yang seimbang, tetapi setiap individu memiliki porsi pada otoritasnya masing-masing.

2. Alasan yang digunakan oleh anggota keluarga dalam melakukan komunikasi verbal dan nonverbal tersebut sebagian besar adalah untuk melepaskan dan atau menenangkan emosi yang muncul pada anak indigo jika mengalami sesuatu ataupun melakukan sesuatu baik negatif maupun positif, serta ada pula yang Tetapi ada yang memiliki alasan untuk mengajarkan anak indigo mengenai bahaya dari emosi yang dimiliki oleh anak indigo secara berlebihan.

3. Dalam menyampaikan masalah, anak indigo lebih memilih orang yang mempercayainya sejak awal. Karena sejak awal anggota keluarga tersebut percaya, maka anak indigo lebih memilih anggota keluarga tersebut sebagai tempat 
menyampaikan masalah. Tapi, selain mempercayai, anggota keluarga yang memberikan pembinaan secara andragogi lebih membuat anak indigo mau terbuka daripada anggota keluarga yang memberikan pembinaan secara pedagogi.

4. Penyelesaian masalah yang digunakan pun berbeda-beda. Bagi anggota keluarga yang sudah mempelajari indigo lebih jauh, mereka menjelaskan secara informatif, rasional, dan melakukannya secara andragogi. Sedangkan anggota keluarga yang belum mempelajari indigo secara dalam, menyampaikan penyelesaian masalah secara langsung.

Setelah menarik beberapa simpulan, peneliti memiliki saran terhadap pola komunikasi anggota keluarga yang memiliki anak indigo. Saran tersebut adalah:

1. Anggota keluarga harus memberikan waktu dan kesempatan bagi anak indigo untuk memaparkan apa yang ada dipikirannya, jika tidak, anak indigo akan lebih memilih diam. Selain itu, komunikasi verbal dan nonverbal yang tepat untuk merespon setiap perilaku anak indigo adalah dengan memberikan penjelasan yang informatif, logis, dan rasional, sehingga anak indigo dapat benar-benar mengerti. Dan penjelasan yang diberikan tersebut harus diberikan untuk menyelesaikan masalah yang sedang dia alami pada saat itu. Dalam menyampaikan penjelasan tersebut harus menggunakan komunikasi dua arah. Jangan menggunakan cara otoriter karena anak indigo akan melawan atau bahkan tidak mau berbicara sama sekali kepada anggota keluarga. Lalu, anggota keluarga juga disarankan untuk mempelajari indigo secara dalam sehingga bisa mengetahui cara yang tepat dalam mendidik dan membina anak indigo.

2. Awalnya, anggota keluarga harus mengetahui apa penyebab anak indigo berperilaku seperti itu. Selain itu anggota keluarga juga harus bisa menjelaskan bahwa emosi yang dimiliki oleh anak indigo secara berebihan bisa berbahaya bagi anak indigo tersebut ataupun orang lain. Sehingga anggota keluarga harus menjadi pengontrol bagi anak indigo dalam mengatur kadar emosinya.

3. Anggota keluarga harus konsisten dalam menggunakan penggunaan pembinaan andragogi kepada anak indigo. Dan juga, anggota keluarga harus mencoba mempercayai perkataan anak indigo dan melihat menggunakan "kacamata" anak indigo tersebut sehingga anak indigo mau terbuka seutuhnya kepada anggota keluarga tersebut.

4. Anggota keluarga harus menjawab dengan jelas dan memberitahukan segala konsekuensi dari pemecahan masalah tersebut. Dan juga anggota keluarga harus 
mencoba mendorong anak indigo tersebut memecahkan masalahnya sendiri dan memaparkan pemikirannya dalam memecahkan masalahnya tersebut.

5. Perlu dilakukan penelitian dengan metode penelitian kuantitatif agar mendapatkan hasil yang lebih akurat lagi mengenai pola komunikasi anggota keluarga yang memiliki anak indigo.

\section{DAFTAR PUSTAKA}

Effendy, Uchjana Onong. 2004. Ilmu Komunikasi Teori dan Praktek. Bandung: PT. Remaja Rosdakarya 1989. Kamus Komunikasi. Bandung: Mandar Maju. 2002. Dinamika Komunikasi. Bandung: PT. Remaja Rosdakarya.

Mulyana, Deddy. 2005. Ilmu Komunikasi: Suatu Pengantar. Bandung: PT. Remaja Rosdakarya.

Ardianto, Elvinaro dan Bambang Q-Anees. 2007. Filsafat Ilmu Komunikasi. Bandung: Simbiosa Rekatama Media.

Soeprapto, Riyadi. 2007. Teori Interaksi Simbolik. Averroes Community -Membangun Wacana Kritis Rakyat. Melalui http://www.averroes.or.id/research/teori-interaksionismesimbolik

West, Richard dan Lynn H. Turner. 2008. Pengantar teori Komunikasi:Analisis dan Aplikasi. Buku 1 edisi ke-3. Terjemahan. Maria Natalia Damayanti Maer. Jakarta: Salemba Humanika.

Djamarah, Syaiful Bahri. 2004. Pola Komunikasi Orang Tua \& Anak dalam Keluarga. Rineka Cipta. Jakarta.

Creswell, J. W. 1998. Qualitatif Inquiry and Research Design. Sage Publications, Inc: California

Mulyana, Deddy. 2013. Metodologi Penelitian Kualitatif. Bandung: PT. Remaja Rosdakarya. Moleong, Lexy J. 2006. Metodologi Penelitian Kualitatif. Bandung:PT. Remaja Rosdakarya . 2012. Metodologi Penelitian Kualitatif: Edisi Revisi. Bandung: PT. Remaja Rosdakarya

Miles, M.B. \& Huberman, A.M. 1994. Qualitative data analysis : an expanded sourcebook, 2nd ed. Thousand Oaks : Sage Publications.

Yin, Robert K.2002. Studi Kasus: Desain \& Metode. Jakarta: PT. Raja Grafindo Persada 
Sumarwan, Ujang, 2004, Perilaku Konsumen, Teori dan Penerapannya dalam Pemasaran, Ghalia Indonesia, Jakarta.

Rohim, Syaiful H., 2009, Teori Komunikasi, Persepektif, Ragam \&Aplikasi, Jakarta: Rineka Cipta.

DeVito, Joseph A, 2001, The Interpersonal Communication Book, AddisonWesley, Longman, NewYork.

Widjaja, H.A.W, 2000, IImu Komunikasi Pengantar Studi, Jakarta: Rineka Cipta.

Cangara, Hafied. 1998. Pengantar Ilmu komunikasi. Jakarta: Raja Grafindo Persada.

Sendjaja, Djuarsa. 2004. Teori Komunikasi. Jakarta: Universitas Terbuka.

Leathers, D.G. 1976. Nonverbal Communication System. Sydney: Allyn and Bacon, Inc.

Rakhmat, Jalaludin. 1985. Psikologi Komunikasi. Bandung : PT Remaja Rosadakarya

Hardjana, Agus M. 2003. Komunikasi Intrapersonal \& Komunikasi Interpersonal, Yogyakarta: Kanisius.

Salim, Dr. Agus. 2006, Teori dan Paradigma Penelitian Sosial. Edisi kedua, Yogyakarta: Tiara Wacana

Kusuma, Tubagus Erwin. Pengenalan dan Pengembangan Anak Indigo (Nila Putra). Slide Power Point yang digunakan di berbagai seminar

Sugiyono. 2011. Metode Kuantitatif, Kualitatif dan R\&D. Bandung: Alfabeta

Sumber Lain:

http://dilihatya.com/2589/pengertian-anak-menurut-para-ahli-adalah

http://www.idjoel.com/pengertian-anak-menurut-para-ahli/

http://www.godsdirectcontact.or.id/news/news186/fr_26.htm

http://www.indospiritual.com/artikel_mengenal-karakteristik-anak-

indigo.htm/\#.VP3MffmsWYA

http://www.mediametafisika.com/2013/06/hal-yang-menarik-dari-anak-indigo.htm/

http://health.detik.com/read/2012/10/03/125720/2053511/775/4-kemampuan-unik-

dari-anak-indigo

http://www.wartainfo.com/2015/01/tentang-anak-indigo-tanda-ciri-fisik.htm/

http://mediaonlinenews.com/lain-lain/fenomena-anak-indigo 